\title{
Adaptacja studentów zagranicznych na uczelniach jako główne wyzwanie edukacji migracyjnej w Polsce
}

\section{KEYWORDS}

educational migration, international students, adaptation, communication, adaptation and language programs

\begin{abstract}
Kozula Magdalena, Adaptacja studentów zagranicznych na uczelniach jako główne wyzwanie edukacji migracyjnej $w$ Polsce [Adaptation of international students at universities as a main challenge of educational migration in Poland]. Kultura - Społeczeństwo - Edukacja nr 1(13) 2018, Poznań 2018, pp. 91-104, Adam Mickiewicz University Press. ISSN 2300-0422. DOI 10.14746/kse.2018.13.7.
\end{abstract}

The aim of this article is to show the broaden perspective on actions taken by universities in the area of adaptation and the influence of adaptation and language programs on the further performance of international students in the academic environment. What does influence the process of acculturation and how is it correlated with the ability to learn and work in the receiving society? The paper concludes with a few reflections on the role of how the adaptation program should be seen by the universities and why is it important for education of foreigners.

\section{Wprowadzenie}

Migracje ludnościowe stanowią obecnie jeden z najbardziej aktualnych problemów globalnych. Choć masowe przemieszczenia ludności znane są od czasów starożytnych, to dopiero w XX wieku podjęto naukową analizę adaptacji kulturowej oraz współbudowania relacji społecznych środowisk imigranckich w kraju noclegowego zamieszkania (Koryś, Okólski, 2004: 3). Przeobrażenia gospodarcze, obecny charakter stosunków międzynarodowych oraz rosnący poziom życia i edukacji, a także dostępność transportu wpływają w znaczący sposób na dynamikę migracji w krajach wysoko rozwiniętych. 
XXI wiek to okres „cywilizacji informatyczno-informacyjnej, której elementem jest formowanie społeczeństw opartych na wiedzy" (Mydel, 2011: 123). Budowanie społeczeństwa o takim charakterze jest nierozerwalnie związane z mobilnością edukacyjną. Odzwierciedleniem tego trendu są statystki - publikacje ICEF Monitor podają, że liczba studentów międzynarodowych na świecie wyniosła w roku 2014 pięć milionów (ICEFMonitor). Aspekt migracji akademickich coraz mocniej uwypukla wielowymiarowy charakter przemieszczeń. Jednym z aktorów na scenie procesu migracyjnego opartego na czynniku edukacji są bezsprzecznie uczelnie wyższe. Obecność studentów zagranicznych sprzyja podjęciu nowych wyzwań - zarówno w wymiarze umiędzynarodowienia curriculum, jak i wspólistnienia różnych grup narodowych w przestrzeni uczelni oraz reorganizacji aspektów administracyjnych pracy. Coraz wyraźniej podnoszony jest także temat pewnej odpowiedzialności uczelni za funkcjonowanie studentów z obcych krajów w nowym środowisku oraz ich wdrożenie - jako przyszłych absolwentów - w struktury miejscowego rynku pracy i otoczenia społecznego, co stanowi szeroką perspektywę w spojrzeniu na zagadnienie rekrutacji studentów zagranicznych.

\section{Emigracja edukacyjna do Polski}

W historii migracji edukacyjnych Polska nie odgrywała nigdy istotnej roli i nie stanowiła szczególnie atrakcyjnej destynacji. Dopiero okres po II wojnie światowej, a szczegółowiej rzecz ujmując, lata pięćdziesiąte XX wieku to czas - początkowo niewielkiego - napływu studentów obcokrajowców na uczelnie wyższe w naszym kraju (Żołędowski, 2010: 54). Istotnym czynnikiem wpływającym na pojawienie się cudzoziemców były programy kształcenia dla tak zwanych krajów Trzeciego Świata, a główne kierunki studiów, jakie podejmowali obcokrajowcy, to medycyna oraz nauki ścisłe (Ruda, 2014: 28). Liczba tych studentów stosunkowo długo utrzymywała się na niskim poziomie, nie przekraczając trzech tysięcy aż do lat osiemdziesiątych ${ }^{1}$. Znaczący i bardziej dynamiczny wzrost obserwuje się w latach dziewięćdziesiątych, co wiązane jest głównie z przemianami gospodarczo-politycznymi, poszerzeniem oferty uczelni wyższych oraz rozwojem struktur stypendialnych przeznaczonych dla osób polskiego pochodzenia i Polaków zamieszkujących za granicą. Koniec XX wieku to liczba studentów obcokrajowców sięgająca ponad sześć tysięcy osób (Żołędowski, 2010: 54).

Ostatnie dziesięć lat edukacji wyższej w Polsce to najbardziej znaczący wzrost liczby obcokrajowców podejmujących studia zarówno na uczelniach państwo-

\footnotetext{
${ }^{1}$ Dane Głównego Urzędu Statystycznego; za: Hut, Jaroszewska, 2011.
} 
wych, jak i prywatnych. Raport Study in Poland 2015 wskazuje, iż w roku akademickim 2014/2015 studiowało w Polsce 46101 studentów zagranicznych, co stanowi wzrost o ponad $28 \%$ w stosunku do poprzedniego roku (Siwińska, 2015). Choć wynik ten to zaledwie 1,02\% wkładu naszego kraju w światowy rynek studentów cudzoziemskich, to analiza wskaźnika umiędzynarodowienia polskich uczelni w latach 2005-2015 wskazuje na unikalny dla polskiego szkolnictwa wyższego wzrost - z 0,52\% w roku akademickim 2005/2006 do 3,14\% w roku 2014/20152.

Statystyki nie są jedynym zagadnieniem, na jakie warto spojrzeć, rozważając aspekty internacjonalizacji uczelni wyższych w Polsce. Zjawiska silnie powiązane ze wzrostem liczby studentów zagranicznych to także: uwypuklenie takich potrzeb, jak perspektywa holistyczna w zarządzaniu umiędzynarodowieniem na uczelni (Mazurek, 2016: 48), uaktywnienie poziomu makro związanego z obecnością studentów zagranicznych, w tym włączenie się ustawodawcy w procesy legislacyjne ${ }^{3}$, czy - a może przede wszystkim - zwiększenie świadomości dotyczącej roli uczelni w procesie adaptacji kulturowej i integracji studentów zagranicznych.

\section{Migracje edukacyjne do Polski - szersza perspektywa}

Dynamiczny rozwój rekrutacji zagranicznych studentów na polskie uczelnie w swym źródłowym charakterze związany jest przede wszystkim z niżem demograficznym w Polsce i zmniejszającą się liczbą studentów. Ten swoisty „środek zaradczy" na wyzwania związane z egzystencją głównych aktorów rynku edukacji wyższej w Polsce nie pozostaje bez związku z szerszym spojrzeniem i pewnymi konsekwencjami dotyczącymi przyjazdu studentów cudzoziemców do Polski. Międzynarodowa Organizacja ds. Migracji (IOM) wyróżnia podstawowe czynniki wpływające na wybór studiów przez kandydatów zagranicznych: „polityka migracyjna kraju docelowego, możliwość zatrudnienia w kraju docelowym, uznawalność wykształcenia, koszt studiów, koszty utrzymania, opinia o studiach, dostępność uczelni (egzaminy, numerus clausus), sieć wsparcia, atrakcyjność kraju, infrastruktura dla studentów" (Jaroszewska, 2011). Co wydaje się istotne, wśród wymienionych czynników nie wyróżniono w sposób bezpośredni zagadnienia

${ }^{2}$ Dane Głównego Urzędu Statystycznego; za: Siwińska, 2015.

${ }^{3}$ Migracja edukacyjna w Polsce jest wyraźnie wspierana w ostatnim czasie przez wiele aspektów natury prawnej oraz instytucjonalnej, za takie możemy uznać m.in. uwzględnienie stopnia umiędzynarodowienia studiów podczas dokonywania oceny przez Państwową Komisję Akredytacyjną czy liberalizację dostępu studentów studiów stacjonarnych oraz absolwentów do rynku pracy w wyniku rozporządzenia Ministra Pracy i Polityki Społecznej z 21 kwietnia 2015 r. 
zorganizowanego procesu adaptacyjnego oferowanego przez uczelnie. Brak wskazanej kategorii związany może być z wciąż dość enigmatycznym charakterem tego typu działań, który mierzalny jest w postaci efektów - takie czynniki jak opinia o uczelni czy sieć wsparcia są przecież pośrednim rezultatem odpowiednio prowadzonej polityki adaptacyjnej cudzoziemców na uczelniach. Także konsekwencje związane z możliwością zatrudnienia w kraju docelowym nie pozostają bez związku z budową kapitału społecznego w trakcie studiów.

Nowe warunki egzystencji w obcym kulturowo środowisku oraz często inny charakter odbywania nauki stanowią największe wyzwania dla studentów zagranicznych po przyjeździe do kraju docelowego. Migracja edukacyjna w szczególny sposób związana jest z pojęciem tak zwanej „akulturacji”, czyli „procesu kulturowych przeobrażeń wywołanych przepływem treści między odmiennymi kulturowo zbiorowościami” (Zenderowski, Koziński, 2012: 58). Proces ten istotny jest z punktu widzenia studentów, gdyż pozwala nie tylko na opanowanie kodu kulturowego i swobodną komunikację z otoczeniem, ale także na nawiązanie skutecznych interakcji w nowym środowisku oraz osiągnięcie takiego stanu psychicznego, który pozwala na odczuwanie satysfakcji (Baranowska, 2015). Kompetencje takie umożliwiają stopniowo coraz łatwiejsze funkcjonowanie w środowisku nie tylko akademickim, ale także chociażby otoczeniu zawodowym. Z tej perspektywy emigracja edukacyjna do Polski może - i powinna - jawić się jako zjawisko przynoszące „zarówno społeczne oraz kulturowe, jak i ekonomiczne korzyści” (Main, Sydow, 2015: 101) dla społeczeństwa. „Wytwarzanie dochodu” przez studentów zagranicznych związane jest nie tylko $\mathrm{z}$ wkładem finansowym na uczelnie w postaci opłat czesnego, ale także jako potencjalny wkład w rozwój gospodarki i nauki. Kolejnym dodatnim efektem jest także zjawisko dyfuzji kulturowej, które w dobie globalizacji stanowi niezbędny element kompetencji, a jest szczególnie istotne w kraju o ujednoliconym systemie etnicznym i narodowym, takim jak Polska. Jak wskazuje Sylwia Ruda: „Mając na uwadze korzystne zmiany, które wraz z fenomenem wędrówek edukacyjnych młodzieży akademickiej mogą zajść w Polsce, warto tworzyć wszelkie projekty i inicjatywy powodujące, iż liczba studentów zza granicy będzie wciąż zwiększała się" (Ruda, 2014: 28).

\section{Wyzwania dla migrantów edukacyjnych}

Wskazane powyżej zjawisko akulturacji jednostki związane jest $\mathrm{z}$ wyzwaniami, jakie emigrujący student spotyka podczas pobytu i edukacji w obcym kraju. Konieczność wypracowania i rozwinięcia narzędzi komunikacji z otoczeniem odnieść możemy przede wszystkim do problemów natury: 
- językowej, które ograniczają samodzielność i poczucie bezpieczeństwa;

- kulturowej, związanych z innym kapitałem kulturowym emigranta;

- instytucjonalno-prawnej, wpływających na ograniczenie korzystania z usług instytucji w danym kraju;

- ekonomicznej, wynikających najczęściej z braku dostatecznej znajomości języka, ale też rynku i prawa pracy w kraju przyjmującym.

Język polski ${ }^{4}$, a dokładniej swobodna komunikacja w tym języku, stanowi warunek konieczny właściwego i pełnego funkcjonowania studenta - w jego życiu akademickim i budowaniu relacji oraz możliwości poza uczelnią. „Zgodnie z wytycznymi przyjętymi przez Radę Europy, poziom biegłości językowej badamy w pięciu obszarach - sprawdzamy rozumienie ze słuchu oraz rozumienie tekstu pisanego, umiejętność tworzenia wypowiedzi pisemnych i artykułowania wypowiedzi ustnych, a także umiejętność wchodzenia w interakcję językową z rozmówcą" (Laskowska, 2016: 263). Na podstawie tak technicznego i przejrzystego w swej konstrukcji opisu umiejętności posługiwania się językiem obcym można uznać, iż po przedstawieniu przez kandydata na studia certyfikatu potwierdzającego odpowiedni poziom znajomości języka polskiego uczelnia ma pewność, iż kandydat taki studia podejmie bez większych trudności. Wrażliwość języka i stopień możliwości komunikacyjnych weryfikowany jest jednak dopiero poprzez autentyczny udział studenta cudzoziemca w zajęciach akademickich, nie zaś przez przedstawiony w procesie rekrutacji dokument. Szczególnie w sytuacji podjęcia studiów z tak zwanymi native speakerami. Studenci zagraniczni wskazują często na trudności związane z rozumieniem tekstów pisanych, szczególnie pod presją czasu w trakcie testu lub egzaminu: „(...) często zdarza się, że cudzoziemcy doskonale rozumieją komunikaty mówione (na przykład dorastali w domu, w którym babcia i dziadek mówili w danym języku), ale nie potrafią zrozumieć tekstów zapisanych" (Laskowska, 2016: 263). Ograniczenie stanowi też umiejętności szybkiej reakcji w dyskusji podczas zajęć na uczelni, obawa przed byciem niezrozumiałym lub wykpionym przez otoczenie, jeżeli popełni się błąd językowy. Tematy abstrakcyjne podejmowane podczas zajęć akademickich wymagają dużej sprawności językowej, która otwiera możliwość wyrażania poglądów studenta i wdrażania pomysłów, na przykład podczas grupowej pracy projektowej. Niejednokrotnie okazuje się, że uzyskanie kwalifikacji językowych poprzez system oceny certyfikatowej nie przystaje w dalszej kolejności do realiów związanych z pierwszymi doświadczeniami studentów zagranicznych na zajęciach w języku polskim. „Pamiętajmy więc, że

\footnotetext{
${ }^{4}$ Opracowanie odnosi się do studentów zagranicznych podejmujących studia w języku polskim.
} 
cudzoziemcy, którzy posiadają stopień języka wystarczający, aby podjąć studia, to grupa niejednorodna" (Laskowska, 2016: 263).

Wpływ na umiejętności komunikacyjne imigranta ma nie tylko baza leksykalno-gramatyczna, ale także znajomość kontekstu kulturowego i związanych z nim zasad w określonym środowisku. Do pełnej i sprawnej komunikacji oraz do zrozumienia otoczenia student zagraniczny musi „także zdobyć wiedzę z obszaru realiów kulturowych, pozyskać kompetencję socjokulturową oraz posługiwać się tym samym kodem kulturowym co naturalny nosiciel języka" (Tambor, Achtelik, 2016: 259). Dotyczy to nie tylko takich zjawisk, jak znajomość elementów kultury, popkultury lub historii, która umożliwia właściwe rozszyfrowywanie komunikatów podczas zajęć lub nieformalnych dyskusji z kolegami z roku. Student obcokrajowiec spotyka się często z problemami dotyczącymi form adresatywnych, grzecznościowych czy „nieznajomością zasad rządzących komunikacją niewerbalną i relacyjną w nowej kulturze" (Baranowska, 2015). Sytuacje takie są jedynie egzemplifikacją tezy Sapira i Whorfa ${ }^{5}$ o relatywizmie językowym.

Wskazując na szczególną sytuację studentów cudzoziemców, należy zwrócić uwagę także na czynnik kulturowy w odniesieniu do samej uczelni. Możemy tu mówić zarówno o ogólnym kontekście kulturowym, jak też o kontekście akademickim. Na skomplikowaną sytuację studenta zagranicznego uczestniczącego w zajęciach na uczelni wpływają nie tylko braki językowe związane z językiem branżowym lub technicznym, ale także nieznajomość przywołanego kontekstu akademickiego. Inne doświadczenia i wzory kulturowe dotyczące nauczania, uczenia się oraz wykonywania podstawowych czynności związanych ze studiowaniem ${ }^{6}$ stanowią znaczący problem na początku studiów. Studenci zagraniczni mogą nie mieć wiedzy na temat metod pracy grupowej wykorzystywanych na uczelni lub różnic w sposobie partycypacji w wykładach i konwersatoriach. Problem ten wydaje się wyraźniejszy, jeżeli odniesiemy go do sytuacji studentów polskich, którzy wiedzę i wzory dotyczące studiowania najczęściej czerpią z doświadczeń najbliższego otoczenia. Odpowiadając na to zagadnienie, uczelnie amerykańskie czy brytyjskie nie bez przyczyny oferują w swoich programach studiów zajęcia typu Academic Writing lub Group Working, zaznajamiając tym samym świeżo upieczonych adeptów nauki z kontekstem akademickim.

Niedostateczne umiejętności językowe oraz brak znajomości zasad funkcjonowania uczelni wpływają na ograniczenia związane z korzystaniem $\mathrm{z}$ usług in-

5 Teoria lingwistyczna opracowana w latach trzydziestych XX wieku, postulująca, że używany język wpływa w mniejszym lub większym stopniu na sposób myślenia, jaki reprezentujemy.

${ }^{6}$ Takich jak pisanie, aktywne uczestnictwo w zajęciach, realizacja projektów etc. 
frastruktury uczelni. „Studenci zagraniczni mają zatem trudność z dopełnieniem różnych formalności na uczelni czy w urzędach" (Baranowska, 2015). Kontekst akademicki obejmie tu przede wszystkim kwestie związane z dokumentami aplikacyjnymi na przykład o stypendia lub akademiki, aktami prawnymi uczelni (na przykład regulamin studiów), drogą komunikacji z uczelnią i jej wykładowcami (na przykład różnorodne formy intranetu obecne już na polskich uczelniach), znajomość skali ocen, czy nawet umiejętność poprawnego odczytywania planu zajęć. Podobne wyzwania czekają na tę grupę w środowisku pozauczelnianym - w przywołanych już urzędach, punktach obsługi oraz w związku z różnymi elementami życia, takimi jak procedura najmu mieszkania czy uzyskania ubezpieczenia zdrowotnego. Wszędzie, gdzie niezbędna jest znajomość nie tylko przepisów, ale przede wszystkim kodu społecznego i kulturowego umożliwiającego ich interpretację.

Wskazane wśród czynników problemy natury ekonomicznej stanowią w dużej mierze konsekwencje opisanych powyżej zjawisk. Ograniczenia natury językowej i kulturowej uniemożliwiają szybkie podjęcie dodatkowej pracy zarobkowej, zaś koszt studiów w Polsce znacznie obciąża rodzinę pozostającą w kraju pochodzenia ${ }^{7}$. Wśród zagranicznych studentów odbywających studia I i II stopnia w Wyższej Szkole Bankowej we Wrocławiu aż 80\% badanych wskazało, iż studia oraz pobyt w Polsce jest finansowany przez rodzinę (Majkut, Pluta, 2015). Często problemy finansowe wpływają na obniżone poczucie wartości takich studentów i wyrzucają ich poza nawias życia towarzyskiego związanego z wydatkami. „Znaczna część respondentów w czasie wolnym od obowiązków uczelnianych po prostu pracuje (...). Co więcej odsetek osób wskazujących na pracę jako sposób spędzania wolnego czasu w przypadku studentów studiów uzupełniających wzrasta z 35\% - licencjat aż do 45\%” (Majkut, Pluta, 2015: 41).

\section{Koncepcja academic success oraz wpływ kursów adaptacyjnych}

Stany Zjednoczone stanowią jeden z głównych kierunków migracji edukacyjnych od czasu zakończenia II wojny światowej i wzrostu mobilności akademickiej (Ota, 2013). Wieloletnie doświadczenia tego giganta światowego rynku edukacyjnego w znaczący sposób są dziś widoczne w procesie tak zwanego transition to American higher education system. Amerykański system edukacji

7 Problem dotyczy głównie studentów zza wschodniej granicy Polski, lecz jest istotny ze względu na wysoki udział tych studentów w grupie studentów zagranicznych. 
wyższej, odwołujący się do koncepcji akademickiego sukcesu, osiągania jak najlepszych wyników i ukończenia studiów, wyposażony został w elementy edukacji „przejścia”, umożliwiające studentom o różnorodnym kapitale społecznym odpowiednie wdrożenie w obecny tam kontekst akademicki. Wspominane już w pracy zajęcia obejmujące naukę umiejętności pisania tekstów naukowych czy pracy w grupach projektowych to elementy sprzyjające budowie takiego właśnie kapitału społecznego, który umożliwia pełną partycypację studenta zagranicznego w życiu akademickim. Przykład tego typu działań i zajęć skierowanych do studentów obcokrajowców zebrało i opracowało amerykańskie The Center for Global Education, odpowiedzialne za promocję międzynarodowej edukacji cross-kulturowej. Wśród zestawionych programów znajdziemy między innymi zajęcia The Culture of Higher Education in the U.S., zapoznające studenta z praktykami akademickimi w Stanach Zjednoczonych, Transitions for International Students, sfokusowane na budowaniu odpowiednich umiejętności związanych z nauką na amerykańskiej uczelni, czy szersze w swoim zasięgu merytorycznym zajęcia Bridges to University Success, skupiające się także na aspektach emocjonalnych związanych z podjęciem studiów za granicą .

Dobre praktyki amerykańskich uczelni nie ograniczają się jedynie do specjalnie opracowanych zajęć akademickich, choć te stanowią niewątpliwie innowacyjny przykład dla polskich uczelni. Szereg działań związanych z tak zwaną orientacją studentów zagranicznych obejmuje między innymi programy tutoringowe i adaptacyjne, stałe wsparcie typu International Students Assistance, warsztaty rozwoju kariery, projekty integrujące młodzież amerykańską ze studentami międzynarodowymi czy pomoc psychologiczną. Tak kompleksowe podejście do zjawiska migracji edukacyjnej jest oczywiście uwarunkowane zarówno skalą owej migracji, jak i doświadczeniem ogólnospołecznym w kraju, który został zbudowany przez imigrantów. Co jednak istotne, integruje ono pozytywne efekty dla obu stron procesu - studentów zagranicznych oraz kraju i uczelni przyjmujących. Na skutek odpowiednio zbudowanego zaplecza uczelni wspomniany sukces akademicki jest dużo bardziej dostępny dla studentów zagranicznych. Posługując się teorią piramidy Maslowa (ryc. 1), możemy stwierdzić, iż zaspokojenie podstawowych potrzeb związanych z bezpieczeństwem, afiliacją czy uznaniem wpływa na możliwości samorealizacji człowieka.

${ }^{8}$ Pełny wykaz programów zebranych przez Center for Global Education dostępny na stronie: http://globaled.us/internationalization/academic-advisement-for-international-students.asp\#table, dostęp: 29.06.2016. 


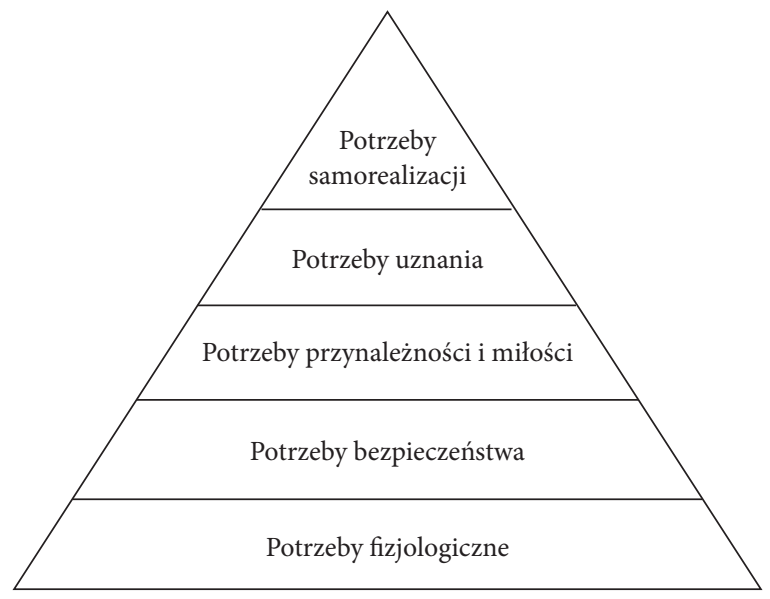

Ryc. 1. Piramida potrzeb Maslowa. Źródło: http://ebookinga.com/pdf/piramida-potrzeb-maslowa

„Poczucie przynależności do grupy rówieśniczej i środowiska akademickiego są czynnikami istotnymi dla fizycznego i psychicznego zdrowia studentów" (Łazarewicz, Werner, 2016: 269), co bezpośrednio wiąże się z potrzebą rozwoju programów adaptacyjnych na polskich uczelniach. Odpowiednio zbudowane i zaprojektowane programy dają szansę na poprawę poczucia bezpieczeństwa, wyjście naprzeciw zmaganiom $\mathrm{z}$ nieumiejętnością poszukiwania i rozkodowywania informacji, zapobiegają izolacji i słabym wynikom w nauce. Tym samym zwiększają aktywność udziału studentów cudzoziemców w życiu społecznym miasta, przyczyniają się do większego zaangażowania $\mathrm{w}$ działania na uczelni oraz zwiększają szansę na aktywizację zarobkową tej grupy. Te pozytywne konsekwencje wpływają w docelowym momencie na ukończenie studiów przez studentów zagranicznych oraz - często - na decyzję o pozostaniu w kraju przyjmującym.

\section{Kursy adaptacyjno-językowe jako przykład projektu adaptacji językowej i kulturowej}

Realizacja kursów adaptacyjnych odpowiadających na opisane w pracy wyzwania wymaga nie tylko odpowiedniego zaplanowania struktury programu, ale także szerszej interakcji i współpracy różnych jednostek na uczelni oraz zaangażowania tychże podmiotów i studentów w realizację programu. Przy czym należy zwrócić uwagę, iż kursy adaptacyjno-językowe obejmujące okres przed rozpoczęciem roku akademickiego winny stanowić początek procesu adaptacyjnego i sposobność 
do wskazania studentom tych obszarów, w których, po pierwsze, mogą uzyskać wsparcie, a, po drugie, w których o to wsparcie powinni się ubiegać - młodzi ludzie bywają często nieświadomi na początku swojej drogi migracyjnej, jakie wyzwania mogą na nich czekać po podjęciu studiów za granicą.

W najbardziej zoptymalizowanej wersji budowa programu powinna mieć swoje umocowanie w następujących krokach:

1) Wyznaczenie celów programu.

2) Budowa zespołu odpowiedzialnego bezpośrednio i pośrednio za realizację ww. celów.

3) Odpowiednie zaplanowanie i przygotowanie programu.

4) Obserwacja, wyciąganie wniosków i analiza programu po jego zakończeniu.

5) Stworzenie narzędzi oceniających efektywność działań przewidzianych w programie, cykliczne badanie tychże efektów i ciągła modyfikacja programu względem potrzeb.

Wyznaczanie celów programu adaptacyjno-językowego powinno być ukierunkowane na realizację zadań związanych z adaptacją, integracją oraz wsparciem, przy czym poprzez adaptację rozumiemy zarówno aspekty językowe, kulturowe, jak i społeczne. Właściwe wyznaczenie celów oraz dróg ich realizacji pozwala na „przejście z okresu aplikowania na uczelnię do bycia studentem i obniża niepokój związany z tym procesem" (Łazarewicz, Werner, 2016: 274). Na podstawie przeprowadzonej analizy i rozważań możemy wskazać, iż cele te powinny ujmować:

- szerokie i elastyczne podejście do doskonalenia języka i komunikacji werbalnej;

- integralne nauczanie języka i kultury;

- aspekty pracy akademickiej;

- aspekty zaznajomienia z uczelnią od strony administracyjnej;

- zapoznanie z miastem i przestrzenią społeczną nowego otoczenia;

- elementy wsparcia coachingowego oraz warsztaty rozwojowe (np. związane $\mathrm{z}$ budową $\mathrm{CV}$, poszukiwaniem pracy na lokalnym rynku);

- elementy informacyjne: spotkania dotyczące zasad i regulacji pobytu cudzoziemców w Polsce, co istotne - przedstawione w sposób zrozumiały i przyjazny;

- możliwości związane ze wsparciem na uczelni oraz w mieście.

Odpowiedni zespół oraz strategiczny podział obszarów zaangażowania i odpowiedzialności stanowi w wielu przypadkach o powodzeniu realizowanych projektów. „Sprawne funkcjonowanie wielowątkowego systemu umiędzynarodowienia w uczelni jest niezbędnym warunkiem osiągania sukcesów w tej dziedzinie. 
Klasyczne, tak zwane funkcyjne „silosowe” podejście do tej tematyki często nie sprzyja skutecznemu realizowaniu celów, gdyż większość z tych działań wymaga kompetencji skupionych w różnych komórkach organizacyjnych" (Mazurek, 2016: 52-53). Przykładem takiego sieciowego podejścia powinna być realizacja kursów adaptacyjnych przez wiele komórek na uczelni, z dodatkowym wsparciem pozauczelnianym. Poza oczywistym udziałem koordynatora kursu i jego bezpośredniego wsparcia w postaci - zazwyczaj - zespołu współpracy międzynarodowej, za istotny należy uznać udział lektorów językowych, którzy są przewodnikami w obszarze kultury, którą reprezentują (Tambor, Achtelik, 2016: 255). Ścisła współpraca nad programem nauczania $\mathrm{w}$ trakcie kursów (ale także po ich zakończeniu) to istotny czynnik, który pozwala na zbudowanie bazy adaptacji studentów zagranicznych.

Obszar pracy akademickiej ze studentami zagranicznymi związany jest z koniecznością włączenia $\mathrm{w}$ sam proces adaptacyjny pionu dydaktycznego uczelni. Budowanie świadomości związanej z istotą takiego rozwiązania jest szczególnie istotne dla omawianej koncepcji academic success. To właśnie wykładowcy są grupą tych pracowników uczelni, z którymi studenci wchodzą w najbardziej zintensyfikowaną relację. Nadanie tej relacji specjalnego wymiaru w kontekście studenta zagranicznego jest jak najbardziej wskazane, co podkreślają przywołane w pracy doświadczenia uczelni amerykańskich. Zaangażowanie pracowników naukowo-dydaktycznych w proces „przejścia” do polskiego systemu edukacji poprzez włączenie tej grupy w programy adaptacyjne jest nie tylko potrzebne, ale wręcz stanowi warunek wyrównania szans studentów zagranicznych w procesie nauczania.

Ważnym uczestnikiem procesu adaptacyjnego jest także pion administracyjny uczelni. Spotkania informacyjno-zapoznawcze z wybranymi działami obsługi studenta, takimi jak uczelniane biura karier, biblioteki, dziekanaty etc., pozwalają na zrozumienie procesów funkcjonujących na uczelni, wyposażenie studenta w elementy wsparcia instrumentalnego oraz także emocjonalnego - przełamanie barier związanych z korzystaniem z oferty oraz usług dostępnych na uczelni. Włączanie jednostek typu biura karier oraz działów bezpośrednio związanych z rozwojem studenta stanowi podstawę w sprzyjaniu realizacji celu związanego ze wsparciem coachingowym oraz realizacją warsztatów aktywizacyjnych. Ważną rolę w szeroko rozumianej aktywizacji studenta obcokrajowca odgrywa także integracja i interakcja ze studentami starszych lat - zarówno zagranicznymi, jak i polskimi. Tak zwane „przetarcie ścieżek” we włączeniu się w działalność kół i organizacji naukowych oraz, co ważne dla młodych ludzi, w bieg życia towarzyskiego na uczelni i w mieście - odbywa się szybciej i sprawniej dzięki współdziałającej przy kursach adaptacyjnych oraz $\mathrm{w}$ całorocznym procesie adaptacji sieci buddies. Zaangażowa- 
nie studentów zagranicznych wyższych lat na etapie budowania i planowania kursu to także ważny czynnik wprowadzania elementów adaptacji, które częstokroć „człowiek z zewnątrz” może nieświadomie pominąć. Ich doświadczenia i wiedza stanowią źródło informacji zarówno dla studentów zagranicznych I roku, jak i dla pracowników uczelni.

Zewnętrzni aktorzy procesu adaptacyjnego to także przedstawiciele instytucji związanych z obecnością obcokrajowców w Polsce i w danym ośrodku miejskim. Spotkania informacyjne i warsztaty z pracownikami fundacji, organizacji miejskich czy urzędów to odpowiedź na wyzwania związane z adaptacją na każdym szczeblu, ponieważ zakres działalności i usług omawianych podmiotów obejmuje zarówno aspekty językowo-kulturowe, instytucjonalne, jak i społeczno-aktywizacyjne.

Niezbędnym, choć często niezaangażowanym w sposób bezpośredni, członkiem zespołu powinien być także przedstawiciel władz uczelni. Holistyczne spojrzenie na kwestie umiędzynarodowienia zakłada, że właśnie na poziomie władz uczelni odbywa się umocowanie organizacyjne procesu internacjonalizacji (Mazurek, 2016: 47-55), co powoduje, że proces taki wraz z jego wszelkimi modelowymi inicjatywami - jak programy adaptacyjne - nie powinien się odbywać bez wsparcia władz.

Obserwacja, gotowość na wprowadzanie zmian i wyciąganie wniosków dla przyszłych projektów adaptacyjnych stanowią o ich powodzeniu w długofalowym i perspektywicznym wymiarze. W przypadku programów i kursów adaptacyjnych istotne jest, aby ewaluacja opierała się na ocenie wartości oferowanego wsparcia i była prowadzona zarówno przed rozpoczęciem projektu, w jego trakcie, jak i po zakończeniu. Pozwala w ten sposób na skompletowanie zbioru rekomendacji odnoszących się zarówno do użyteczności samych projektów adaptacyjnych, jak też podnoszenia ich skuteczności oraz sygnalizacji przeszkód i problemów. Dodatkowo da możliwość uaktywnienia procesu uczenia się wszystkich osób zaangażowanych w projekt, co stanowi wartość dodaną w procesie internacjonalizacji w przytoczonym ujęciu holistycznym.

\section{Podsumowanie}

Reasumując, przedstawiony w artykule problem obecności studentów zagranicznych w Polsce i aspektów adaptacyjnych tej grupy jest zjawiskiem niezwykle aktualnym dla polskich uczelni, lecz także - zjawiskiem nowym. Wkraczając w tę istotną fazę zwiększonego napływu obcokrajowców podejmujących w naszym kraju 
studia, nie można zapominać o szerszych aspektach przyjmowania studentów zagranicznych, niźli bezpośrednie dochody finansowe oraz walka ze zjawiskiem niżu demograficznego. Rekrutacja studentów obcokrajowców to także pewne zobowiązanie polskich uczelni do odpowiedzi na pytanie: Co dalej? Odwołanie do doświadczeń bardziej doświadczonych uczelni, holistyczne zaangażowanie, obserwacja i wyciągnie wniosków oraz wspomniane poczucie odpowiedzialności stanowi istotny element działań, który pozwoli podjąć temat migracji edukacyjnych do Polski z korzyścią dla wszystkich stron tego procesu.

\section{Literatura}

Baranowska A.S. (2015). Tutoring akademicki jako forma wsparcia studentów zagranicznych w adaptacji do nowych warunków życia i nauki w Polsce. „Journal of Modern Science” nr 2/25, s. 195218. http://yadda.icm.edu.pl/yadda/element/bwmeta1.element.desklight-47ab1b40-b12c-4707a0b9-39ee1934129a, dostęp: 28.06.2016.

Center for Global Education. http://globaled.us/internationalization/academic-advisement-for-international-students.asp\#table, dostęp: 29.06.2016.

Hut P., Jaroszewska E. (2011). Studenci zagraniczni w Polsce na tle migracji edukacyjnych na świecie. Badania. Ekspertyzy. Rekomendacje. http://www.isp.org.pl/uploads/pdf/772873926.pdf, dostęp: 29.06.2016.

ICEF Monitor, The growth of international students mobility 1990-2014, http://monitor.icef. com/2015/11/the-state-of-international-student-mobility-in-2015/, dostęp: 29.06.2016.

Jaroszewska E. (2010). Edukacja studentów zagranicznych w liczbach, https://sites.google.com/site/ biulletynmigracyjny/archiwum-html/biuletyn-migracyjny-26/bm26art4, dostęp: 28.06.2016.

Koryś P., Okólski M. (2004). Czas globalnych migracji. Mobilność międzynarodowa w perspektywie globalizacji. „Prace Migracyjne” nr 55, s. 1-33.

Laskowska J. (2016). Mosty, a nie bariery - rzecz o komunikacji. [W:] B. Siwińska, M. Zimnak (red.). Czas internacjonalizacji. Warszawa, s. 262-268.

Łazarewicz M., Werner B. (2016). Rola uczelni w adaptacji kulturowej, integracji i wsparciu psychospołecznym studentów zagranicznych. [W:] B. Siwińska, M. Zimnak (red.). Czas internacjonalizacji. Warszawa, s. 269-277.

Main I., Sydow K. (2015). Migranci edukacyjni, Źródło dochodu czy pełnoprawni mieszkańcy miasta? [W:] N. Bloch, I. Main, K. Sydow (red.). Nie dość użyteczni. Zmagania imigrantów na lokalnym rynku pracy. Poznań, s. 101-123.

Majkut R., Pluta J. (2015). Jakość i warunki kształcenia studentów obcokrajowców studiujących w Wyższej Szkole Bankowej we Wrocławiu. Raport z badań, maszynopis raportu wewnętrznego. Wroclaw 2015.

Mazurek G. (2016). Zarządzanie uczelnia międzynarodowa - perspektywa krajowa - Akademia Leona Koźmińskiego. [W:] B. Siwińska, M. Zimnak (red.). Czas internacjonalizacji. Warszawa, s. 47-55.

Mydel R. (2011). Wielkość i kierunki geograficzne wspótczesnej emigracji edukacyjnej Polaków. [W:] A.M. Kargol, W. Masiarz (red.). Nietypowe migracje Polaków w XIX-XXI wieku. Kraków, s. $123-132$. 